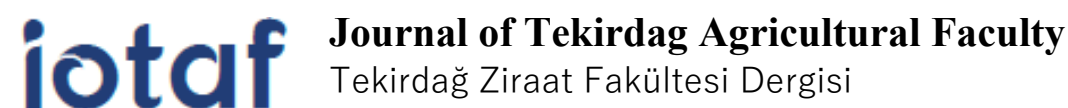

\section{Investigating of Some Agricultural and Quality Traits of Advanced Barley (Hordeum vulgare $\mathrm{L}$.) Lines}

\author{
İleri Kademe Arpa (Hordeum vulgare L.) Hatlarının Bazı Tarımsal ve Kalite Özelliklerinin \\ Araştırılması
}

\author{
Ali Cevat SÖNMEZ
}

\begin{abstract}
To meet the increasing raw material demand of the livestock and food sectors in our country is a need for new high-quality barley varieties that have a short vegetation period, resistance to lodging, homogeneous and plump grain, high grain and biomass yield, and compatible with the climate of the Central Anatolia Region. To meet this need, it was aimed to determine the appropriate lines by comparing 18 advanced barley lines belonging to the Transitional Zone Agricultural Research Institute with the standard varieties widely grown in the region. The trials were carried out in two locations, Eskişehir Center and Hamidiye fields of the Transitional Zone Agricultural Research Institute in the 2017-2018 crop year, in rainfed conditions. The trials were set up as a randomized complete block design with 4 replications in Eskişehir and 3 replications in Hamidiye. In the study, grain yield, days to heading, plant height, lodging score, thousand-grain weight, plump grain ratio, grain protein, and betaglucan ratio properties of the breeding material were investigated. According to the results of the analysis of variance by combining the location averages, the differences between genotypes in all parameters except the betaglucan ratio were found to be statistically significant. In the study were obtained that grain yield is between 4.56$6.67 \mathrm{t} \mathrm{ha}^{-1}$; days to heading are between 115.4 - 124 days; plant height is between $81.6-101.4 \mathrm{~cm}$; lodging score is between $0-100 \%$; thousand-grain weight is between $35.7-47.4 \mathrm{~g}$; the plump grain ratio is between $52.0-94.3 \%$; grain protein content is between $10.05-12.75 \%$; B-glucan values are between $3.67-4.33 \%$ were obtained. Also, in the correlation analysis, a negative relationship was found significant between grain yield and days to heading, lodging score, and protein content characteristics, while a relationship was found significant to be positive with the plump grain ratio feature. When all the parameters are evaluated together, it is seen that lines $8,11,13,14,18$, and 22 stand out as candidates for variety.
\end{abstract}

Keywords: Barley, Grain yield, Correlation, Quality, Selection

\footnotetext{
1*Sorumlu Yazar/Corresponding Author: Ali Cevat SÖNMEZ, Geçit Kuşağı Agricultural Research Institute, Ziraat St. No:396 Tepebaşı, Eskişehir, Turkey Email: alicevat.sonmez@tarimorman.gov.tr (D) OrcID: 0000-0002-9818-2660

Atıf/Citation: SÖNMEZ A.C. Investigating of Some Agricultural and Quality Traits of Advanced Barley (Hordeum vulgare L.) Lines. Tekirdă̆ Ziraat Fakültesi Dergisi, 18 (3), 545-556.

(CBu çalışma Tekirdağ Namık Kemal Üniversitesi tarafından Creative Commons Lisansı (https://creativecommons.org/licenses/by-nc/4.0/) kapsamında yayınlanmıștır. Tekirdağ 2021
} 


\section{Öz}

Ülkemizdeki hayvancılık ve gıda sektörlerinin giderek artan hammadde talebini karşılamak için Orta Anadolu Bölgesi iklim koşullarına uyumlu vejetasyon süresi kısa, yatmaya dayanıklı, homojen ve dolgun taneli, yüksek tane ve biyomas verime sahip kaliteli yeni arpa çeşitlerine ihtiyaç vardır. Bu ihtiyacı gidermek amacıyla Geçit Kuşağı Tarımsal Araştırma Enstitüsü 'ne ait ileri kademe 18 adet arpa hattı bölgede yaygın olarak yetiştirilen standart çeşitlerle kıyaslanarak uygun hatların belirlenmesi hedeflenmiştir. Denemeler 2017-2018 ürün yılında yağışa bağımlı koşullarda Geçit Kuşağı Tarımsal Araştırma Enstitüsü ’nün Eskişehir Merkez ve Hamidiye deneme arazileri olmak üzere iki lokasyonda yürütülmüştür. Denemeler tesadüf blokları deneme deseninde Eskişehir de 4 tekerrürlü ve Hamidiye de ise 3 tekerrürlü olarak kurulmuştur. Araştırmada ıslah materyalinin tane verim, başaklanma süresi, bitki boyu, yatma değeri, bin tane ağırlığı, dolgun tane oranı tane protein ve beta-glukan oranı özellikleri incelenmiştir. Lokasyon ortalamaları birleştirilerek yapılan varyans analizi sonuçlarına göre beta-glukan oranı dışında tüm parametrelerde genotipler arasındaki farklılıklar istatistiksel olarak anlamlı bulunmuştur. Denemede ortalama olarak tane verim 4.56-6.67 $\mathrm{t} \mathrm{ha}^{-1}$ arasında; başaklanma süresi 115.4-124 gün arasında; bitki boyu 81.6-101.4 cm arasında; yatma değeri \% 0-100 arasında; bin tane ağırlığı 35.7-47.4 g arasında; dolgun tane oranı \%52.0-94.3 arasında; tane protein içeriği \% 10.05-12.75 arasında; ß-glukan oranı ise \% 3.67-4.33 arasında elde edilmiştir. Ayrıca yapılan korelasyon analizinde tane verim ile başaklanma süresi, yatma değeri ve tane protein oranı özellikleri arasında olumsuz ilişki anlamlı görülürken, dolgun tane oranı özelliği ile olumlu ve önemli bulunmuştur. Tüm özellikler birlikte değerlendirildiğinde $8,11,13,14,18$ ve 22 nolu hatların çeşit adayı olarak öne çıktıkları görülmüştür.

Anahtar Kelimeler: Arpa, Tane verim, Korelasyon, Kalite, Seleksiyon 


\section{Introduction}

Barley (Hordeum vulgare L.) is one of the first plants to be domesticated by humanity (Smith and Nesbitt, 1995) and continues to play an essential role in modern agriculture today (Harwood, 2019). Although barley is mostly consumed as animal feed in our country, a little remaining of it is also used for malt production. Also, its use as a functional food is gradually increasing due to its content of dietary fibers, proteins, $\beta$-glucan, and arabinoxylan, which have a positive effect on human health (Baik and Ulrich, 2008; Köten et al., 2013).

The animal feed raw material production is inadequate in Turkey and was 3.9 billion USD paid for import in 2018 (Özkan, 2020). Increasing barley production will play an important role in meeting this need and reducing imports. Turkey is a significant barley producer with 8.3 million tons (Anonymous, 2021a) produced in 2020, 5.3\% of the world production (Anonymous, 2021b), which was 156.4 million tons in total, was realized. Due to the development of animal husbandry and the fact that barley is earlier maturing than wheat, barley production is increasing as the first crop in areas where two crops can be grown per year (Öztürk et al., 2007). Lodging is one of the factors that cause crucial yield and quality loss in barley during the years when rainfall is high and these losses can be prevented by using durable cultivars (Sönmez and Yüksel, 2019). Plump grain size and homogeneity are some of the traits desired by the malt industry and are taken into account in determining the barley price (Sönmez et al., 2020).

The amount of precipitation falling in Central Anatolia regions and its distribution by months is quite variable. For this reason, there is a need for varieties that have a limited decrease in grain yield and quality in years when rainfall is low in the region, but that can increase yield and quality as much as possible when favorable conditions are seen. The breeding of new barley varieties that meet the livestock and malt industry's quality criteria with high yield potential will contribute to barley's enhancement production. Turkey 's first modern winter barley cultivar Güzak24 was registered by Emcet Yektay at Transitional Zone Agricultural Research Institute (TZARI) in 1937 (Sönmez et al., 2017). Since then, many barley cultivars were registered in the ongoing breeding studies here (Yüksel et al., 2011). In this study, it is aimed to determine the lines with short vegetation periods, resisted to lodging, plumped grain size, high grain yield, and quality by comparing the advanced barley lines of TZARI with the varieties commonly grown in the region under rainfed conditions.

\section{Materials and Methods}

\subsection{Plant materials, experiment site, and trial management}

As the material, advanced barley lines belonging to TZARI were used, and the pedigrees of the lines and the names of the standard varieties are given in Table 1.

Table 1. The pedigree of lines and the names of control varieties in the research

\begin{tabular}{|c|c|c|c|}
\hline $\begin{array}{l}\text { Genotype } \\
\text { Number }\end{array}$ & Cultivar-Pedigree & $\begin{array}{l}\text { Genotype } \\
\text { Number }\end{array}$ & Cultivar-Pedigree \\
\hline 1 & İnce-04 & 13 & Cwb117-5-9-5/ST5819//Kalaycı \\
\hline 2 & Ünver & 14 & Sonata/Cwb117-5-9-5//Cw117-77-9-7 \\
\hline 3 & Larende & 15 & Impact/Kalaycı \\
\hline 4 & Burakbey & 16 & Aydanhanım/ST5822 \\
\hline 5 & Tarm-92 & 17 & Impact/Kalaycı \\
\hline 6 & Erginel-90 & 18 & $\begin{array}{l}\text { Cum//1246Lignee/78sakız/3/4654perga/4376Union//59TH/4/ } \\
\text { Özdemir-05 }\end{array}$ \\
\hline 7 & Narcis/Gk Omega & 19 & ZDM 1454/Zeynelağa \\
\hline 8 & Clerine/Pompa & 20 & Gk Omega/Kalayc197 \\
\hline 9 & $\begin{array}{l}11 \text { th/P15-B27281//ST4652/TOK/3/ } \\
\text { YEA389-3/YEA475-4 }\end{array}$ & 21 & EFES-3/97-98DH4 \\
\hline 10 & 3896 VTGX1- 15XCUM Somut//Zeynelağa & 22 & ST124/97-98DH4 \\
\hline 11 & Bolayır/Sonata & 23 & $\begin{array}{l}\text { Ste/Antares//Viringa's/3/Angora/4/Sunrise/Ciho } 15865 \\
\text { HO88ID SD Ciho } 15865 \text { Azure/5/Aydanhanım/6/Tarm-92 }\end{array}$ \\
\hline 12 & YEA389-3/YEA475-4//97-98DH8 & 24 & ST5807/Zeynelağa \\
\hline
\end{tabular}


Investigating of Some Agricultural and Quality Traits of Advanced Barley (Hordeum vulgare L.) Lines

Field trials were established at TZARI Eskişehir Central campus (39 $49^{\circ} 30^{\prime \prime} \mathrm{N}, 30^{\circ} 23^{\prime} 44^{\prime \prime} \mathrm{E}$, Altitude 800

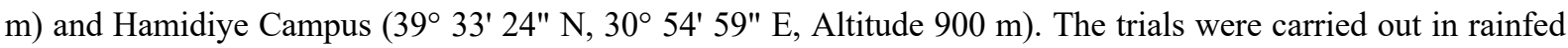
conditions during the 2017-2018 crop growing season, and the precipitation and temperature values of the trial sites by months are given in Table 2 (Anonymous, 2020). Eskişehir Central fields have a higher yield potential with a deep soil profile, clay soil structure, and a lower lime ratio. Hamidiye campus fields have low GY potential with shallow and clay-loam soil structure and high lime ratio. Field trials were established in a randomized complete block design with four replications in the Eskişehir campus and three replications in the Hamidiye. Plots were sowed in six rows sized $7.0 \mathrm{~m} \times 1.2 \mathrm{~m}$ with a $20 \mathrm{~cm}$ distance between rows using a seeder. Seed sowing was carried on the second week of October at a sowing density of 500 seeds $\mathrm{m}^{-2}$. Fertilization was made according to soil analysis results and before planting, $30 \mathrm{~kg} \mathrm{ha}^{-1} \mathrm{~N}$ and $70 \mathrm{~kg} \mathrm{ha}^{-1} \mathrm{P} 2 \mathrm{O}$; In the spring, $40 \mathrm{~kg} \mathrm{ha}^{-1} \mathrm{~N}$ was applied at the stem elongation period. Herbicide with 2-4 D EHE + Florasulam effective ingredients was used to combat broadleaf weeds. The plots were harvested using a combined harvester as $5 \mathrm{~m}$ length on the first week of July.

Table 2. The means of long-term of some climatic data in Eskisehir District and monthly mean values for the trial years

\begin{tabular}{lcccccc}
\hline & \multicolumn{3}{c}{ Precipitation (mm) } & \multicolumn{2}{c}{ Temperature $\left({ }^{\circ} \mathbf{C}\right)$} \\
\cline { 2 - 6 } \multicolumn{1}{c}{ Months } & \multicolumn{2}{c}{ Eskişehir } & \multicolumn{2}{c}{ Hamidiye } & Eskişehir & Hamidiye \\
\cline { 2 - 6 } & $\mathbf{2 0 1 7 - 2 0 1 8}$ & MLY* & $\mathbf{2 0 1 7 - 2 0 1 8}$ & MLY & $\mathbf{2 0 1 7 - 2 0 1 8}$ & $\mathbf{2 0 1 7 - 2 0 1 8}$ \\
\hline September & 0.5 & 14.4 & 2.5 & 9.6 & 19.6 & 19.6 \\
October & 48.4 & 26.1 & 41.5 & 23.5 & 10.7 & 10.2 \\
November & 28.6 & 29.8 & 20.0 & 21.0 & 5.5 & 4.9 \\
December & 41.8 & 46.1 & 28.0 & 33.1 & 3.9 & 3.0 \\
January & 28.8 & 38.2 & 78.0 & 34.1 & 1.6 & 0.8 \\
February & 41.6 & 32.5 & 22.5 & 25.7 & 5.8 & 5.1 \\
March & 41.1 & 33.4 & 39.0 & 30.6 & 9.3 & 9.0 \\
April & 9.5 & 35.2 & 13.0 & 31.0 & 13.8 & 13.0 \\
May & 92.5 & 43.3 & 108.5 & 35.3 & 16.7 & 16.2 \\
June & 73.8 & 28.6 & 35.0 & 20.6 & 19.9 & 19.5 \\
July & 59.9 & 13.5 & 37.0 & 6.7 & 22.2 & 22.0 \\
\hline Total & 466.5 & 341.1 & 425.0 & 271.2 & 129.9 & 123.3 \\
\hline Monthly Average & 42.4 & 31.0 & 38.6 & 24.7 & 11.7 & 11.2 \\
\hline
\end{tabular}

*MLY: Means of many years

\subsection{Data collection and analysis}

Grain yield was calculated that obtained crop from the harvested parcels with the plot combine harvester was weighed in grams after cleaning and converted in ton ha-1. Days to heading were determined as the number of days from the beginning of the year following seed sowing until the date when more than half of the plants in the plot completely removed their spike from the flag leaf (Öztürk et al., 2016). Plant height was determined as $\mathrm{cm}$ by measuring the distance from the soil level of 10 plants from each plot to the tip of the uppermost spikelet excluding the awn. The lodging score was obtained by multiplying these two values by determining the percentage of plants showing lodging in the plots and the lodging angle (Pask et al., 2012). Thousand-grain weight was calculated by counting four hundred grains from the grains taken from the harvested product and weighing them in precision scales (Williams et al., 1988). Plump grain ratio was determined by using sieve analysis was made in the Sortimat device according to ICC standard 102/1 and 103/1 protocols (Pfeuffer GMB, Kitzingen, Germany). Samples (100 g) were shaken for 3 minutes in the sieve shaker, and the diameter sizes (large $>2.8 \mathrm{~mm}$; medium $=2.8-2.5 \mathrm{~mm}$; thin $=2.5-2.2 \mathrm{~mm} ; 2.2 \mathrm{~mm}<$ under sieve) divided into four different sieve groups and the amount of those divided into groups was determined as a percentage (Özkaya and Özkaya, 2005). While the grains in the large and large- 
medium groups were collected to form the plump grain ratio group, the weak and under-sieve grains were not considered. Grain protein content and beta-glucan ratio were determined by Near-Infrared Spectroscopy (NIR 6500, Foss, Hillerød, Denmark) device from whole grain flour. The device for grain protein content was calibrated according to American Association of Cereal Chemists International (AACCI) methods (46-19.01) and (32-23.01), respectively (Anonymous, 2010). Megazyme $\beta$-glucan analysis kits and absorbance values were measured at 510 $\mathrm{nm}$ in the spectrophotometer (McCleary and Codd, 1991). Statistical analysis was made using the JMP statistical program. Levene test was performed before the locations were analyzed together, and the equality of variances was checked. The significance of the differences between genotypes was determined by conducting the variance analysis "F" test. The least significant difference (LSD) test was used for the comparison of the means (Student, 1908). Correlation analysis was performed according to Pearson's (1920) method using corrected mean values. The mean squares and variance analysis table obtained from the parameters investigated are presented in Table 3. The average values of the genotypes were grouped at $\mathrm{p}<0.05$ level according to the LSD test and compared and presented in Table 4.

\section{Results and Discussion}

\subsection{Grain yield (GY)}

When the results of the experiment were evaluated with analysis of variance, differences between genotypes and genotype $\mathrm{x}$ environment interaction were found to be significant at $\mathrm{p}<0.01$, while differences between environments were significant at $\mathrm{p}<0.05$ (Table 3). Average GY was 5.70 tons $^{-1} \mathrm{~h}^{-1}$ in the experiment, while 5.90 $\mathrm{t}$ ha ${ }^{-1}$ from the lines; $5.11 \mathrm{t} \mathrm{ha}^{-1}$ average GY was obtained from control varieties (Table 4).

Table 3. Mean squares values of traits examined in the research and its significance status

\begin{tabular}{lccccccc}
\hline \multicolumn{1}{c}{ Traits } & & Replications & Environment & Genotypes & Gen x Env. & Error & Total \\
\hline \multirow{2}{*}{ Grain yield } & DF & 5 & 1 & 23 & 23 & 115 & 167 \\
& MS & 0.61 & $4.90^{*}$ & $1.87^{* *}$ & $0.94^{* *}$ & 0.46 & 0.78 \\
Days to heading & DF & 5 & 1 & 23 & 23 & 115 & 167 \\
& MS & 1.99 & $601.29 * *$ & $57.04 * *$ & $3.94 * *$ & 4.38 & 10.86 \\
Plant height & DF & 5 & 1 & 23 & 23 & 115 & 167 \\
& MS & $121.46^{* *}$ & 218.04 & $192.98^{* *}$ & 37.48 & 30.31 & 57.21 \\
Lodging score & DF & 5 & 1 & 23 & 23 & 115 & 167 \\
& MS & 557.98 & $9800.61^{* *}$ & $7592.58^{* *}$ & 450.79 & 440.85 & 1533.39 \\
Thousand grain weight & DF & 3 & 1 & 23 & 23 & 69 & 119 \\
& MS & $49.11^{* *}$ & 10.80 & $21.36^{* *}$ & 4.52 & 4.70 & 11.29 \\
Plump grain ratio & DF & 3 & 1 & 23 & 23 & 69 & 119 \\
& MS & $172.44^{* *}$ & 1104.01 & $248.83^{* *}$ & $40.42 * *$ & 15.22 & 97.84 \\
Grain protein content & DF & 3 & 1 & 23 & 23 & 69 & 119 \\
& MS & $3.55^{* *}$ & 3.72 & $1.88^{* *}$ & $0.92^{* *}$ & 0.35 & 0.86 \\
Grain B-glucan ratio & DF & 3 & 1 & 23 & 23 & 69 & 119 \\
& MS & $0.67^{* *}$ & 3.65 & 0.07 & 0.11 & 0.08 & 0.13 \\
\hline
\end{tabular}

${ }^{* *}$ : Significant at the level $p<0.01 ;{ }^{*}$ : Significant at the level $p<0.05 ; D F$ : Degree of freedom; MS: Mean square

The highest GY of the lines was taken from line13 with 6.67 tons ha $^{-1}$, followed by line22 with $6.43 \mathrm{t} \mathrm{ha}^{-1}$ and line15 with $6.25 \mathrm{t} \mathrm{ha}^{-1}$ (Table 4). When the environments were examined, $5.88 \mathrm{tha}^{-1}$ from the Eskişehir location, and higher GY than Hamidiye was obtained (Table 4). In the 2017-2018 crop year, from seed sowing to the end of May, the end of the vegetation period, Eskişehir location received more than $11.3 \%$ high rainfall from many years, with $332.8 \mathrm{~mm}$ rainfall, while Hamidiye location was $353.0 \mathrm{~mm}$ and it received $44.7 \%$ higher precipitation than its many years (Table 2). Thus, an average GY of $5.88 \mathrm{tha}^{-1}$, which can be considered high, was obtained for conditions based on rainfall in the Eskişehir. Although the soils are less fertile, much higher than expected GY was obtained from Hamidiye location due to the high rainfall. Similar to this study, Sönmez et al. (2017) reported that $4.90 \mathrm{t} \mathrm{ha}^{-1}$ was obtained from Eskişehir location and $4.07 \mathrm{t} \mathrm{ha}^{-1}$ was obtained from Hamidiye. In the study conducted by Aktaş (2017), it was declared that under rainfed conditions, the GY was lower than this study, with $3.36 \mathrm{t} \mathrm{ha}^{-1}$. This situation is compatible with the opinion of Kalayc1 et al. (1991) that the environmental factors that most affect the GY in barley are the precipitation during the growth period of the plant and the distribution of this precipitation during the year, temperature, and agricultural techniques. In this research, lines $8,11,12,13,14,15$, 
Investigating of Some Agricultural and Quality Traits of Advanced Barley (Hordeum vulgare L.) Lines

18 , and 22 prominent with GY values above $6 \mathrm{t}$ ha. This situation is compatible with the research's aim to determine genotypes that can increase productivity under high yield conditions. One of the reasons why genotype $\mathrm{x}$ environment interaction was found significant in the study is that although the lines 7,9 and 11 are among the genotypes with high yield in the Eskişehir environment, they are among the genotypes with low yield in Hamidiye.

Table 4. The mean values of genotypes and environments examined in the research and the comparison of the means, and the LSD and CV informations

\begin{tabular}{|c|c|c|c|c|c|c|c|c|c|c|c|c|c|c|c|}
\hline \multirow{2}{*}{$\begin{array}{c}\text { Genotype No } \\
1\end{array}$} & \multicolumn{2}{|c|}{ GY $\left(\mathrm{t} \mathrm{ha}^{-1}\right)$} & \multicolumn{2}{|c|}{$\begin{array}{l}\text { DTH } \\
\text { (day) }\end{array}$} & \multicolumn{2}{|c|}{ PH (cm) } & \multicolumn{2}{|c|}{ LS (\%) } & \multicolumn{2}{|c|}{ TGW (g) } & \multicolumn{2}{|c|}{ PGR (\%) } & \multicolumn{2}{|c|}{ PC (\%) } & \multirow{2}{*}{$\frac{\text { BGL(\%) }}{4.19}$} \\
\hline & 5.28 & $f-i$ & 122.7 & $\mathrm{~b}$ & 90.0 & d-g & 80.6 & $a b c$ & 40.93 & fg & 84.56 & def & 12.42 & $a-d$ & \\
\hline 2 & 4.56 & $\mathrm{i}$ & 121.3 & d-g & 81.6 & d-g & 67.4 & $c-f$ & 43.90 & $b-g$ & 82.15 & efg & 12.26 & $a-f$ & 4.09 \\
\hline 3 & 5.52 & d-g & 122.5 & $\mathrm{bc}$ & 85.2 & d-g & 76.0 & bcd & 45.79 & $a-d$ & 77.90 & $\mathrm{G}$ & 12.06 & $a-g$ & 4.22 \\
\hline 4 & 5.55 & $\mathrm{c}-\mathrm{g}$ & 121.3 & d-g & 102.5 & $\mathrm{a}$ & 86.3 & $a b c$ & 44.29 & $a-f$ & 91.47 & $\mathrm{Abc}$ & 11.42 & $f-i$ & 4.05 \\
\hline 5 & 4.63 & hi & 121.8 & b-e & 94.1 & $c-f$ & 100.0 & $\mathrm{a}$ & 42.50 & d-g & 78.96 & $\mathrm{Fg}$ & 12.75 & $\mathrm{a}$ & 4.09 \\
\hline 6 & 5.11 & ghi & 120.3 & ghi & 100.3 & $\mathrm{ab}$ & 70.6 & b-e & 35.66 & $\mathrm{~h}$ & 52.01 & $\mathrm{H}$ & 11.50 & d-h & 4.02 \\
\hline 7 & 5.80 & $b-g$ & 118.8 & $\mathrm{jk}$ & 94.8 & bcd & 21.7 & $\mathrm{ij}$ & 46.80 & $\mathrm{ab}$ & 92.15 & $\mathrm{Ab}$ & 11.55 & $\mathrm{~d}-\mathrm{h}$ & 3.95 \\
\hline 8 & 6.22 & $a-d$ & 114.1 & o & 90.9 & d-h & 14.7 & $\mathrm{j}$ & 42.11 & efg & 94.30 & $\mathrm{~A}$ & 10.56 & ijk & 3.98 \\
\hline 9 & 5.54 & $c-g$ & 113.2 & o & 99.2 & $a b c$ & 0.0 & $\mathrm{j}$ & 44.83 & $a-e$ & 93.69 & A & 11.78 & $\mathrm{c}-\mathrm{h}$ & 4.24 \\
\hline 10 & 5.64 & c-g & 124.0 & $\mathrm{a}$ & 93.5 & $c-f$ & 38.8 & hi & 42.24 & efg & 86.56 & $b-e$ & 12.73 & $a b$ & 3.98 \\
\hline 11 & 6.04 & a-e & 118.1 & $\mathrm{kl}$ & 88.6 & d-g & 4.3 & $\mathrm{j}$ & 44.84 & a-e & 93.61 & A & 11.45 & $e-i$ & 4.12 \\
\hline 12 & 6.22 & $a-d$ & 121.5 & $c-f$ & 92.0 & d-g & 82.3 & $a b c$ & 46.59 & $a b$ & 85.78 & Cde & 10.05 & $\mathrm{k}$ & 4.18 \\
\hline 13 & 6.67 & $\mathrm{a}$ & 119.1 & $\mathrm{jk}$ & 83.1 & d-g & 1.9 & $\mathrm{j}$ & 41.61 & efg & 91.36 & $\mathrm{Abc}$ & 10.31 & $\mathrm{jk}$ & 3.86 \\
\hline 14 & 6.05 & $a-e$ & 120.7 & fgh & 91.4 & d-g & 9.0 & $\mathrm{j}$ & 44.98 & $a-e$ & 85.35 & Cde & 10.97 & h-k & 3.67 \\
\hline 15 & 6.25 & $a b c$ & 116.9 & $\mathrm{~m}$ & 95.4 & bcd & 45.9 & fgh & 46.24 & $\mathrm{ab}$ & 92.23 & $\mathrm{Ab}$ & 12.18 & $a-f$ & 4.07 \\
\hline 16 & 5.35 & e-h & 119.6 & $\mathrm{ij}$ & 92.2 & d-g & 54.4 & d-h & 47.36 & $\mathrm{a}$ & 90.57 & $a-d$ & 12.38 & a-e & 4.17 \\
\hline 17 & 5.28 & $f-i$ & 120.2 & hi & 94.4 & cde & 63.9 & $\mathrm{c}-\mathrm{g}$ & 40.69 & $\mathrm{~g}$ & 88.22 & $a-e$ & 12.03 & $a-g$ & 4.01 \\
\hline 18 & 6.16 & $a-d$ & 117.4 & $\operatorname{lm}$ & 101.4 & $\mathrm{a}$ & 1.5 & $\mathrm{j}$ & 46.13 & $a b c$ & 94.05 & A & 10.93 & h-k & 4.25 \\
\hline 19 & 5.87 & $b-f$ & 115.8 & $\mathrm{n}$ & 94.8 & bcd & 6.4 & $\mathrm{j}$ & 44.00 & $a-g$ & 92.20 & $\mathrm{Ab}$ & 12.41 & $a-d$ & 4.33 \\
\hline 20 & 5.63 & c-g & 122.3 & bcd & 87.5 & d-g & 52.2 & e-h & 46.33 & $\mathrm{ab}$ & 86.77 & $b-e$ & 12.16 & $a-g$ & 4.16 \\
\hline 21 & 5.93 & $b-f$ & 121.8 & b-e & 92.1 & d-g & 43.5 & ghi & 43.69 & b-g & 84.78 & Def & 11.07 & hij & 3.89 \\
\hline 22 & 6.43 & $a b$ & 117.3 & $\operatorname{lm}$ & 88.3 & d-g & 3.8 & $\mathrm{j}$ & 42.74 & c-g & 92.19 & $\mathrm{Ab}$ & 11.81 & b-h & 4.08 \\
\hline 23 & 5.41 & efg & 121.1 & e-h & 92.2 & d-g & 90.2 & $a b$ & 44.68 & a-e & 89.89 & $a-d$ & 12.68 & $a b c$ & 4.18 \\
\hline 24 & 5.77 & b-g & 115.4 & $\mathrm{n}$ & 95.1 & bcd & 41.4 & hi & 44.81 & $a-e$ & 91.16 & $a b c$ & 11.25 & ghi & 4.14 \\
\hline Means of Trial & 5.70 & & 119.5 & & 92.5 & & 44.0 & & 43.90 & & 87.16 & & 11.70 & & 4.08 \\
\hline Means of Lines & 5.90 & & 118.7 & & 92.6 & & 32.0 & & 44.48 & & 90.27 & & 11.57 & & 4.07 \\
\hline M. C. Varieties & 5.11 & & 121.7 & & 92.3 & & 80.2 & & 42.18 & & 77.84 & & 12.07 & & 4.11 \\
\hline $\operatorname{LSD}(0.05)$ & 0.72 & & 1.06 & & 5.89 & & 22.46 & & 3.41 & & 6.15 & & 0.93 & & 0.45 \\
\hline CV $(\%)$ & 11.80 & & 0.83 & & 5.94 & & 46.53 & & 4.96 & & 4.60 & & 5.01 & & 6.74 \\
\hline \multicolumn{16}{|c|}{ Means of Locations } \\
\hline Eskisehir & 5.88 & A & 117.6 & B & 93.7 & & 51.7 & A & 43.53 & & 83.4 & & 11.92 & & 4.30 \\
\hline Hamidiye & 5.53 & B & 121.4 & A & 91.4 & & 36.3 & B & 44.28 & & 91.0 & & 11.48 & & 3.86 \\
\hline
\end{tabular}

GY: Grain yield; DTH: Days to heading; PH: Plant height; LS: Lodging score; TGW: Thousand-grain weight; PGR: Plump grain ratio; PC: Protein content; $\beta G L: \beta$-glucan; M. C. Varieties: Means of control varieties; LSD: Least significant difference; CV: Coefficient of variation

\subsection{Days to heading (DTH)}

Days to heading is vital in terms of giving an idea about the maturation period of a variety. In the variance analysis performed by combining locations, differences between locations, genotypes, and genotype $\mathrm{x}$ environment interaction were significant at $\mathrm{p}<0.01$ (Table 3). While the average of the experiments was 119.5 days, the mean of the lines was 118.7 days; the control varieties average was 121.7 days. While the trial average was 117.5 days in Eskişehir, this value was 121.4 days in Hamidiye. The shortest DTH was on line9 with 113.2 
days, while the longest DTH was on line10 with 124.0 days (Table 4). Early maturing in barley is an essential feature in terms of drought and disease avoidance and post-harvest second crop forage production (Öztürk et al., 2014). According to Aydin and Katkat (1999), while resistance to drought increases with earliness, the yield potential of the variety also decreases. It is thought that the average of 119.5 days obtained in this study was due to the drought in April caused stress on the plant and shortened the DTH period (Table 1). In a study conducted by Sönmez and Yüksel (2019) in Eskişehir, the average DTH was 136.6 days, while Kara et al. (2019) was found 133.4 days in another study in Konya. The reason for the statistical difference about DTH between the related locations is that the Hamidiye site has an altitude higher than the Eskişehir site and the average temperature values are lower than the Eskişehir. A study was reported that the DTH is shortened under stress conditions (Al-Menai et al., 2013). Among the lines examined in this study, 8, 11, 13 15, 18, and 22 lines were found to stand out in terms of both high yield and earliness. This situation is compatible with the objectives of the study in terms of earliness.

\subsection{Plant height (PH)}

Taller plants have more storage assimilation potential than shorter plants and are drought tolerant. However, tallness enhances the risk of lodging and, therefore, affects flowering negatively and reduces the plant's photosynthetic capabilities (Gholipoor et al., 2013). In the analysis of variance, only the differences between genotypes were found statistically significant $\mathrm{p}<0.01$ (Table 3). While the trial average for $\mathrm{PH}$ is $92.5 \mathrm{~cm}$, the averages of lines, control varieties, and locations are also around this value (Table 4). When the lines were evaluated, the lowest PH was measured $83.1 \mathrm{~cm}$ on line13, while the highest PH was measured $101.4 \mathrm{~cm}$ in line18 (Table 4). Short cultivars have been improved by cereal breeders to reduce lodging and increase grain yield (Yu et al., 2010). However, as barley straw is a valuable product that generates additional income demanded by the livestock sector, PH should be considered in plant breeding. In this study, it is seen that line 18 is the closest line to our breeding objectives with $101.4 \mathrm{~cm}$ PH. In another study conducted by Sönmez and Yüksel (2019) in Eskişehir, the average PH was found to be $84.2 \mathrm{~cm}$ in dry conditions as compatible with this research. Öztürk et al. (2016) reported that PH is a significant element in terms of resistance to the lodging of barley and that short or medium-height varieties with a PH of $85-95 \mathrm{~cm}$ are preferred. According to Kandemir (2004), it can be said that if PH is higher than $100 \mathrm{~cm}$ in barley, lodging is seen. Yüksel et al. (2017) also found between $92.5 \mathrm{~cm}$ and 129.5 cm PH in barley in their study in Eskişehir. Doğan et al. (2014) reported that, although the effect of inheritance is very high in $\mathrm{PH}$, the environmental effect is also important.

\subsection{Lodging score (LS)}

Lodging in cereal is more common in barley plants than wheat and is one of the main factors causing yield losses in many countries (Cenci, 1984). In the variance analysis, the differences between genotypes and environments were found to be significant at the $\mathrm{p}<0.01$ level (Table 3). While the means of experiments was $44.0 \%$, the means of lines were $32.0 \%$; the means of control varieties were $80.2 \%$ (Table 4 ). In the study, the lowest LS value was line 9 with $0.0 \%$, while the line that reached the highest value was line5 with $100 \%$ (Table 4). Although the plant height of the lines used in the trial was almost the same as the control varieties, LS values are lower than control varieties (Table 4). The results in this research indicate that LS value is taken into account at TZARI barley breeding program selection. Alkan and Kandemir (2015) reported that they found LS at a high rate of $68-90 \%$ and resistance to lodging is low for local barley varieties. In a study conducted by Saygll et al. (2019), LS was ranged from $0.0-33.3 \%$ in the first year and between $55.0 \%$ and $77.7 \%$ in the second year. Especially the lines $8,11,13,14,18$ and 22 stand out with low LS values together with high GY. The LS average of the Eskişehir location was $51.7 \%$, and the LS average of $36.3 \%$ was higher than the Hamidiye location (Table 4). When the environments are evaluated, it is thought that higher LS observed in the Eskişehir environment, which has higher yield potential, compared to the Hamidiye environment, is compatible with the expectations (Table 4). It is known that many factors affect LS like wind, falling rain amount, soil characteristics, variety-based plant characteristics, sowing time, sowing frequency, fertilization, and plant growth regulator applications, etc. (Berry et al., 2002). LS is related to plant height, stem thickness and spike weight and generally occurs after heading. According to Akar et al. (1999), a significant yield loss is observed in barley plants due to lodging down in the years when the annual average amount of precipitation exceeds $400 \mathrm{~mm}$ in Central Anatolia and Transitional Zones. Lodging down not only reduces barley yield and grain quality but also indirectly reduces malt quality (Day and Dickson, 1958). PH is a vegetative feature that most affects the LS in barley (Anderson and Reinbergs, 1985). 


\subsection{Thousand-grain weight (TGW)}

TGW is one of the important quality factors in terms of giving an idea about the size, plumpness, thinness of the grain as well as grain yield (Öztürk et al., 2007). In the analysis of both environments together, only the differences between genotypes were found to be statistically significant at the $\mathrm{p}<0.01$ level (Table 3 ). While the trial average was $43.90 \mathrm{~g}$, the average of the lines was $44.48 \mathrm{~g}$; the control varieties average was found to be 42.18 $\mathrm{g}$ (Table 4). When the lines were evaluated, the highest TGW was obtained from line16 with $47.36 \mathrm{~g}$, while the lowest TGW was obtained from line17 with $40.69 \mathrm{~g}$ (Table 4). In this study, all genotypes except Erginel-90, which is a six-row control variety, were above the $40 \mathrm{~g}$ TGW limit, one of the malting quality criteria. The average TGW value found in this study was consistent with the values found by Sönmez and Yüksel (2019). The TGW results obtained in this study were found to be consistent with some studies (Sirat and Sezer, 2009; Aydoğan et al., 2011; İmamoğlu et al., 2016). Koca et al. (2015) was found higher TGW values than this study with $49.6 \mathrm{~g}$. These results show that TGW of barley genotypes occurs under the influence of genotype and environment. TGW controlled by many genes is a feature that varies according to the variety and ecological conditions of the year. Atli et al. (1989) stated that TGW should be higher than $40 \mathrm{~g}$ for malting barley.

\subsection{Plump grain ratio (PGR)}

It has been reported that sieve analyzes in barley provide information about the plumpness of the grain as well as the homogeneity of the grain (Kendal et al. 2010). In the combined variance analysis, differences between genotypes and genotype $\mathrm{x}$ environment interaction were significant at the $\mathrm{p}<0.01$ level (Table 3). Trial averages for PGR were obtained as $87.16 \%$. The means of the lines were found to be higher than the means of control varieties (Table 4). When the lines were evaluated, the highest PGR was obtained from line 8 with $94.30 \%$, while the lowest PGR was obtained from line21 with $84.78 \%$ (Table 4). The lowest PGR value of the trials with, 52.01\%, was obtained from Erginel-90, which is six-row control variety. If the sum of over two sieves (2.2 to 2.5 or 2.5 to 2.8 ) is more than $75 \%$, this sample is considered to be homogeneous in terms of size (Elgün and Certel, 1987). The homogeneity of the grain is important in obtaining homogeneous color in the process of germination and roasting-drying simultaneously in malt production (Sirat, 2014). Except for genotype6, the PGR value of all the material is above $75 \%$ and sufficient for malting criteria. It was reported by Sönmez et al. (2020) that PGR in dry conditions in Eskişehir was lower (75.5\%) than this study. In a study conducted in Konya in dry conditions, PGR was found to be lower (62.5\%) than in this study (Aydoğan et al., 2017). In another study by Sirat and Sezer (2017), consistent with this study, they were found the PGR between $85.3 \%$ and 92.0\%. According to Engin (1989), the correlation between grain size and malt extract ratio is positive and important.

\subsection{Protein content (PC)}

It is one of the essential quality criteria that determine the evaluation of the barley grain as malting. In the combined variance analysis, the differences between genotypes and genotype $\mathrm{x}$ environment interaction were significant at the $\mathrm{p}<0.01$ level (Table 3). The means of the trial was $11.70 \%$. The means of the lines were lower than the means of the control varieties (Table 4). When the lines were evaluated, the highest PC was obtained from line10 with $12.73 \%$, while the lowest PC was obtained from line 12 with $10.05 \%$ (Table 4 ). In the experiment, the highest PC value of the experiment, with $12.75 \%$, was obtained from Tarm- 92 , which is the genotype 5 among the standards. It was reported that PC was found lower than this study with $10.9 \%$ by Öztürk et al. (2016). Aydoğan et al. (2011) reported that they found the average PC as $11.8 \%$ in the first year and $11.3 \%$ in the second year, compatible with this study. Again, in many studies conducted under rainfed conditions, it was reported that the average PC was determined higher than this study with 12.4\% (Doğan et al., 2014; Aydoğan et al., 2016; Sönmez et al., 2020). Many researchers have reported that the amount of PC in the grain may vary according to genotype, environment, and agricultural applications (Fox, 2003; Doğan et al., 2014; Öztürk et al., 2016; K1zılgeçi et al., 2019). PC in malting barley is expected to be between $9-11.5 \%$ (Elgün and Certel, 1987). In this study, lines 8 , $11,12,13,14$ and, 18 were found to be suitable for malting in terms of PC.

\subsection{Beta-glucan (BGL)}

$\beta$-glucan is a high-molecular non-starch polysaccharide, and it is located in the sub-aleurone layer and cell walls of the endosperm in barley between 3-11\% (Wood, 2007). The health benefits of barley ß-glucans include 
reduction of blood cholesterol and glucose and decrease of weight by increased satiety, and hence, control of type2 diabetes and heart diseases (Baik and Ulrich, 2008). According to the results of combined variance analysis, the differences between genotypes and environments and genotype $\mathrm{x}$ environment interaction are not significant (Table 3). While the means of the trial was $4.08 \%$, the means of the lines and the control varieties were also found close to this value (Table 4). When the lines were evaluated, the values of $\beta$ GL between $3.67 \%$ and $4.33 \%$ were obtained (Table 4). In parallel with these results, the differences between genotypes for BGL were found to be insignificant in the study conducted by Kon (2019), and the average BGL was found to be $4.03 \%$ in the first year and 3.77 in the second year. It was reported that the $\beta G L$ is formed under the influence of genotype, mostly environmental conditions (Fox et al., 2003; Kon, 2019).

\subsection{Correlations between traits (GY)}

When the correlations between properties were examined, it was found that there was a negative relationship significant between GY and DTH, LS, and PC, while a positive relationship with PGR trait was found significant. As compatible with this study, some other studies were reported that the negative relationship between GY and DTH is meaningful (Öztürk et al., 2014; Öztürk et al., 2016). Again, it was reported by some researchers that there was a negative correlation between GY and PC, in compatible with this study (Kızılgeçi et al., 2016; Kızılgeçi et al., 2019). While the negative correlation of PGR with DTH and LS was found to be significant $(p<0.05)$, the relationship, with TGW was found to be positively significant $(p<0.01)$. Also, the relationship between DTH and LS was found to be positively significant $(\mathrm{p}<0.01)$ (Table 5).

Table 5. Correlation coefficients and significance status of the traits which was examined in this research

\begin{tabular}{lcccccccc}
\hline & GY & DTH & PH & LS & TGW & PGR & PC & GBL \\
\hline GY & 1 & & & & & & & \\
DTH & $-0.405^{*}$ & 1 & & & & & & \\
PH & -0.046 & -0.272 & 1 & & & & & \\
LS & $-0.667^{* *}$ & $0.657^{* *}$ & 0.022 & 1 & & & & \\
TGW & 0.246 & -0.111 & -0.079 & -0.137 & 1 & & & \\
PGR & $0.502^{*}$ & $-0.446^{*}$ & -0.051 & $-0.482^{*}$ & $0.626^{* *}$ & 1 & & \\
PC & $-0.644^{* *}$ & 0.282 & -0.020 & 0.372 & -0.032 & -0.113 & 1 & \\
GBL & -0.221 & -0.204 & 0.151 & 0.177 & 0.251 & 0.118 & 0.369 & 1 \\
\hline
\end{tabular}

GY: Grain yield; DTH: Days to heading; PH: Plant height; LS: Lodging score; TGW: Thousand grain weight; PGR: Plump grain ratio; PC: Protein content; $\beta G L: \beta$-glucan

\section{Conclusions}

As a result of this research, the candidate lines were evaluated in terms of GY, DTH, PH, LS, TGW, PGR, PC, and BGL parameters. All the parameters were considered together and it was determined that lines $8,11,13,14,18$, and 22 had characteristics compatible with the breeding targets. It is suggested that some of these lines can be offered to the Directorate of Seed Registration and Certification Center as a variety candidate or can be used as a parent in the barley hybrid program.

\section{Acknowledgment}

This work supported by The Republic of Turkey Ministry of Agriculture and Forestry, General Directorate of Agricultural Research and Policy, Transitional Zone Agricultural Research Institute, Eskişehir, Turkey. 


\section{References}

Akar, T., Avcı, M., Düşünceli, F., Tosun, H., Ozan, N., Sipahi, H. (1999). Orta Anadolu ve geçit bölgelerinde arpa tarımının sorunları ve çözüm yolları. Orta Anadolu'da Hububat Tarımının Sorunları ve Çözüm Yolları Sempozyumu, 8-11 Haziran, Konya, Turkey.

Aktaş, H. (2017). Türkiye'de yoğun ekim alanına sahip bazı arpa (Hordeum vulgare L.) çeşitlerinin destek sulamalı ve yağışa dayalı koşullarda değerlendirilmesi. Tekirdă̆ Ziraat Fakültesi Dergisi 2017: 14 (03) p 86-97

Alkan, F., Kandemir, N. (2015). Tokak yerel arpa çeşidi içinden seçilen safhatların bazı gıda, yem ve tarımsal özellikler bakımından varyasyonları. Tarla Bitkileri Merkez Araştırma Enstitüsü Dergisi, 24(2), 124-139.

Al-Menaie, H. S., Mahgoub, H. S., Al-Ragam, O., Al-Dosery, N., Mathew, M., Suresh, N. (2013). Performance and Yield Components of Forage Barley Grown Under Harsh Environmental Conditions of Kuwait. In Advance in Barley Sciences (pp. 367-374). Springer, Dordrecht.

Anderson, M. K., Reinbergs, E. (1985). Barley breeding. Barley, 26, 231-268. Published in Barley, Agronomy Monograph No. 26, (C) ASACSSA-SSSA, 677 South Segoe Road, Madison, WI 53711, USA.

Anonymous, (2010). AACC Approved Methods (10 ${ }^{\text {th }}$ ed.). American Association of Cereal Chemists International (AACC), St. Paul, MN.

Anonymous, (2020). Climate records. Transitional Zone Agricultural Research Institute. Eskişehir, Turkey

Anonymous, (2021a). TUIK istatistikleri. www.tuik.gov.tr (Accessed date: 03.01.2021)

Anonymous, (2021b). World Agricultural Production. Circular Series WAP $12-20 \quad$ December 2020. https://apps.fas.usda.gov/psdonline/circulars/production.pdf (Accessed date: 03.01.2021)

Atlı, A., Koçak, N., Köksel, H., Tuncer, T. (1989). Yemlik ve Maltlık arpada kalite kriterleri ve arpa ıslah programlarında kalite değerlendirmesi. Arpa-Malt Seminerleri, Konya 23-27.

Aydın, M., Katkat, A. V. (1999). Water Consumption and Growth of Some Barley Genotypes Under Eskişehir Conditions. Turkish Journal of Agriculture and Forestry, 23 (EK4):797-802.

Aydoğan, S., Şahin, M., Akçacık, A. G., Ayrancı, R. (2011). Konya koşullarına uygun yüksek verimli ve kaliteli arpa genotiplerinin belirlenmesi. Selcuk Journal of Agriculture and Food Sciences, 25(1), 10-16.

Aydoğan, S., Şahin, M., Akçacık, A. G., Demir, B., Hamzaoğlu, S., Kara, İ. (2016). Yemlik Arpa Genotiplerinin Kalite Özellikleri Açısından Islah Programı Kapsamında Değerlendirilmesi. Bahri Dağdaş Bitkisel Araştırma Dergisi, 5(2), 68-76.

Aydoğan, S., Şahin, M., Akçacık, A. G., Demir, B., Hamzaoğlu, S., Kara, İ. (2017). Arpa genotiplerinin farklı lokasyonlardaki kalite özelliklerinin değerlendirilmesi. Selçuk Tarım ve Gıda Bilimleri Dergisi, 31(2), 8-13.

Baik, B. K., Ullrich, S. E. (2008). Barley for food: characteristics, improvement, and renewed interest. Journal of cereal science, 48(2), 233242.

Berry, P. M., Spink, J. H., Sylvester-Bradley, R., Pickett, A., Sterling, M., Baker, C., Cameron, N. (2002). Lodging control through variety choice and management. In Proceedings of the 8th Home-Grown Cereals Association $R \& D$ Conference on Cereals and Oilseeds, pages (pp. 7-1).

Cenci, C. A., Grando, S., Ceccarelli, S. (1984). Culm anatomy in barley (Hordeum vulgare). Canadian journal of botany, 62(10), $2023-2027$.

Day, A. D., Dickson, A. D. (1958). Effect of Artificial Lodging on Grain and Malt Quality of Fall-sown Irrigated Barley 1. Agronomy Journal, 50(6), 338-340.

Doğan, Y., Kendal, E., Karahan, T., Çiftçi, V. (2014). Diyarbakır koşullarında bazı arpa genotiplerinde verim ve bazı kalite özelliklerinin belirlenmesi. Gaziosmanpaşa Üniversitesi Ziraat Fakültesi Dergisi, 2014(2), 31-40.

Elgün, A., Certel, M. (1987). Tahıl ve ürünlerinde analitik kalite kontrolü. Atatürk Üniversitesi, Ziraat Fakültesi, Tarım Ürünleri Teknolojisi Bölümü, 100-104, Erzurum.

Engin, A. (1989). Biralık arpalarda önemli kalite özellikleri ve bunların malt kalitesi üzerine etkileri. Arpa-Malt Semineri, 30 Mayıs - 1 Haziran, s 38-41, Konya

Fox, G. P., Panozzo, J. F., Li, C. D., Lance, R. C. M., Inkerman, P. A., Henry, R. J. (2003). Molecular basis of barley quality. Australian Journal of Agricultural Research, 54(12), 1081-1101.

Gholipoor, M., Rohani, A., Torani, S. (2013). Optimization of traits to increasing barley grain yield using an artificial neural network. International Journal of Plant Production (2013) 7(1): 1-18

Harwood, W. A. (2019). An introduction to barley: the crop and the model. In Barley (pp. 1-5). Humana Press, New York, NY.

İmamoğlu, A., Pelit, S., Sarı, N., Büyükkileci, C., Yıldız, Ö. (2016). Ege Bölgesi Sahil Kuşağına Uyumlu Arpa (Hordeum vulgare L.) Çeşit ve Genotiplerinin Verim ve Bazı Kalite Özelliklerinin Belirlenmesi. Tarla Bitkileri Merkez Araştırma Enstitüsü Dergisi, 25 (özel sayı-1): $141-145$.

Kalaycı, M., Siirt, S., Aydın, M., Özbek, K. (1991). Yıllık Çalışma Raporu. Transitional Zone Agricultural Research Institute, Eskişehir. 
Kandemir, N. (2004). Tokat-Kazova şartlarına uygun maltlık arpa çeşitlerinin belirlenmesi. Gaziosmanpaşa Üniversitesi Ziraat Fakültesi Dergisi, 2004(2)

Kara, İ., Türköz, M., Yakışır, E., Özer, E., Yaşar, M., .Cerit, Ş. İ. (2019). Konya İli Kuru Şartlarında Arpa (Hordeum vulgare L.) Genotiplerinin Verim ve Bazı Tarımsal Özelliklerinin Araştırılması. Bahri Dağdaş Bitkisel Araştırma Dergisi, 8(1), 21-25.

Kendal, E., Kılıç, H., Tekdal, S., Altıkat, A. (2010). Bazı arpa genotiplerinin Diyarbakır ve Adıyaman kuru koşullarında verim ve verim unsurlarının incelenmesi. Harran Tarım ve Glda Bilimleri Dergisi, 14(2), 49-58.

Kızılgeçi, F., Yıldırım, M., Albayrak, Ö., Akıncı, C. (2016). Bazı arpa genotiplerinin Diyarbakır ve Mardin koşullarında verim ve kalite parametrelerinin incelenmesi. Iğdır Üniversitesi Fen Bilimleri Enstitüsü Dergisi, 6(3), 161-169.

Kızılgeçi, F., Yıldırım, M., Akıncı, C., Albayrak, Ö. (2019). Arpada tane verimi ve kalite özellikleri üzerine genotip ve çevrenin etkileşimi. Kahramanmaraş Sütçü İmam Üniversitesi Tarım ve Doğa Dergisi, 22(3), 346-353.

Koca, Y. O., Erekul, O., Sabancı, S., Zeybek, A., Yiğit, A. (2015). Akdeniz kuşağında yetiştirilen arpa (Hordeum vulgare L.) çeşitlerinde verim unsurları ve tane kalite özelliklerinin belirlenmesi. Adnan Menderes Üniversitesi Ziraat Fakültesi Dergisi, 12(1), 9-15.

Kon, H. İ. F. (2019). Orta Anadolu koşullarında, bazı arpa çeşitlerinin verim, kalite ve azot kullanım randımanlarının azotlu gübreleme miktarlarına göre belirlenmesi. (Ph. D. Thesis) Ankara Üniversity. The Institute of Natural Sciences, Department of Field Crops, Ankara, Turkey

Köten, M., Ünsal, S., Atlı, A. (2013). Arpanın insan gıdası olarak değerlendirilmesi. Türk Tarım-Glda Bilim ve Teknoloji Dergisi, 1, $51-55$.

McCleary, B. V., Codd, R. (1991). Measurement of $(1 \rightarrow 3),(1 \rightarrow 4)-\beta$-D-glucan in barley and oats: A streamlined enzymic procedure. Journal of the Science of Food and Agriculture, 55(2), 303-312.

Özkan, U. (2020). Türkiye Yem Bitkileri Tarımına Karşılaştırmalı Genel Bakış ve Değerlendirme. Turkish Journal of Agricultural Engineering Research, 1(1), 29-43.

Özkaya, H., Özkaya, B. (2005). Tahıl ve Ürünleri Analiz Yöntemleri. A.Ü. Mühendislik Fak. Gıda Müh. Bölümü, Glda Teknolojisi Yayınlarl N0:30, Ankara.

Öztürk, İ., Avcı, R., Kahraman, T. (2007). Trakya Bölgesinde yetiştirilen bazı arpa (Hordeum vulgare L.) çeşitlerinin verim ve verim unsurları ile bazı kalite özelliklerinin belirlenmesi. UÜ Ziraat Fakültesi Dergisi, 21(1), 59-68.

Öztürk, İ., Avcı, R., Kaya, R., Vulchev, D., Popova, T., Valcheva, D., \& Dimova, D. (2014). Bazı arpa (Hordeum vulgare L.) genotiplerinin Edirne koşullarında verim ve bazı tarımsal özelliklerinin incelenmesi. Tarla Bitkileri Merkez Araştırma Enstitüsü Dergisi, 23(2), 41-48.

Öztürk, İ., Avcı, R., Tülek, A., Kahraman, T., Tuna, B. (2016). Bazı Arpa (Hordeum vulgare L) Genotiplerinin Trakya Bölgesinde Verim ve Agronomik Özelliklerinin Araştırılması. Tarla Bitkileri Merkez Araştırma Enstitüsü Dergisi, 25(1).

Pask, A. J. D., Pietragalla, J., Mullan, D. M., Reynolds, M.P. (2012). Physiological Breeding II: A Field Guide to Wheat Phenotyping. Chapter 18. p-100, Cimmyt.

Pearson, K. (1920). Notes on the history of correlation. Biometrika, 13.1: 25-45.

Saygılı, İ., Demir, A., Kandemir, N. (2019). Tokat-Kazova Şartlarının Maltlık Arpa Üretimi Potansiyeli. Türkiye 13. Ulusal, 1. Uluslararası Tarla Bitkileri Kongresi, 01-04 Kasım 2019, Antalya, Turkey

Sirat, A., Sezer, İ. (2009). Bafra ovası koşullarına uygun arpa (Hordeum vulgare L.) çeşitlerinin belirlenmesi.. Anadolu Tarım Bilimleri Dergisi, 24(3), 167-173

Sirat, A. (2014). Orta Karadeniz Bölgesi koşullarına uygun maltlık ve yemlik arpa (Hordeum vulgare L.) çeşitlerinin belirlenmesi. Tekirda Ziraat Fakültesi Dergisi 2014 11(1) p 9-17

Sirat, A., Sezer, İ. (2017). Bafra ovasında yetiştirilen bazı iki sıralı arpa (Hordeum vulgare conv. distichon) çesitlerinin verim, verim öğeleri ile bazı kalite özelliklerinin belirlenmesi. Tekirdag Ziraat Fakültesi Dergisi, 14(1), p 77-87.

Smith, B. D., Nesbitt, M. (1995). The emergence of agriculture (p. 231). New York: Scient. American Library. Nature, 1995, 375.6529: 289289.

Sönmez A. C., Yüksel, S., Belen, S., Çakmak, M., Akın, A. (2017). Kuru koşullarda Orta Anadolu ve geçit bölgeleri için geliştirilen bazı arpa (Hordeum vulgare L.) hat ve çeşitlerinin tane verim ve bazı kalite unsurlarının incelenmesi. KSU Doğa Bilimleri Dergisi, $20,258$.

Sönmez, A. C., Yüksel, S. (2019). İleri Kademe Arpa (Hordeum vulgare L.) Genotiplerinin Verim ve Bazı Fizyolojik Özelliklerinin Eskişehir Koșullarında Belirlenmesi. Kahramanmaraș Sütçü Imam Üniversitesi Tarım ve Doğa Dergisi, 22, 61-69.

Sönmez, A. C., Olgun, M., Yüksel, S., Belen, S., Yıldırım, Y.,Önder, O. (2020). Determining of Grain Yield and Some Malting Quality Characteristics of Advanced Barley (Hordeum vulgare L.) Genotypes in Eskişehir Conditions. Black Sea Journal of Agriculture, 15-16.

Student, (1908). The Probable Error of a Mean. Biometrica. Volume 6, Issue 1, 1-25

Yu, G. T., Horsley, R. D., Zhang, B., Franckowiak, J. D. (2010). A new semi-dwarfing gene identified by molecular mapping of quantitative trait loci in barley. Theoretical and applied genetics, 120(4), 853-861. 

Yüksel, S., İkincikarakaya, S. Ü., Bolat, N., Çakmak, M., Karaduman, Y. (2011). Eskişehir Anadolu Tarımsal Araştırma Enstitüsü Tarafindan 2004-2007 Yılları Arasında Tescil Ettirilen Arpa Çeşitlerinin Bazı Tarımsal Özellikleri. Uluslararası Katılımlı I. Ali Numan Kıraç Tarım Kongresi ve Fuarl 27-30 Nisan, 2011 Eskişehir, Turkey

Yüksel, S., İkincikarakaya, S. Ü., Sönmez, A. C., Belen, S., Yıldırım, Y. (2017). Eskişehir Ekolojik Koşullarında Bazı Arpa Hat ve Çeşitlerinin Verim ve Verim Öğeleri Üzerine Bir Araştırma. Tarim ve Doga Dergisi, 20, 252.

Williams, P., El-Haramein, F. J., Hani, N., \& Safouh, R. (1988). Crop quality evaluation methods and guidelines. (14, Ed. 2.). ICARDA. 142 p. Aleppo, Syria

Wood, P. J. (2007). Cereal $\beta$-glucans in diet and health. Journal of cereal science, 46(3), 230-238. 